\title{
LUPUS ERYTHEMATOSUS.-AN EXAMINATION OF THE NOTES OF FIFTEEN CONSECUTIVE CASES.
}

\section{(Second Comuunication.)}

\author{
By WILFRID B. WARDE, M.D., M.R.C.P.,
}

Assistant Physician to the Hospital for Diseases of the Skin, Blackfriars.

IN a previous communication I made a careful examination of my notes on fifteen cases of Lupus erythematosus, that came under my charge in the Light and Ray Department of the hospital, with special reference to the condition of the nasal and external auditory passages of patients suffering from that disease.

I showed that a large proportion of such cases suffered from either hypertrophic or atrophic Rhinitis, and that more than one-third suffered from ozæna. I also showed that destructive suppurative changes had occurred in two of the cases leading to complete, or partial, loss of the drum. I also showed that quite a large proportion of cases had a marked deficiency of wax in the meatus, and that the lining epithelium was dull white, as if thickened, while the deeper structures appeared to have undergone atrophy. In two instances, I found a scaling erythema affecting the whole meatus. The analogy between the changes in the nose and in the meatus was striking.

Now I propose to give the circulation anomalies, the changes occurring in the auricle of the ear, and the condition of the mucous membrane of the mouth met with in the same series of cases. I have prepared a table corresponding to the one already given. The cases are designated by the same tokens, and are given in the same order. I should have liked to add another column, giving the surface distribution of the disease in each case, but space made it inconvenient to do so.

I propose, however, to do this at the end of this paper, in order that those who wish to may be able to judge of the type of case.

The results obtained are not quite so striking as those mentioned 
in the first communication; but they are, none the less, interesting and suggestive. Taken altogether they are sufficient to rouse in my mind the suspicion that the disease, as we know it, is not a distinct pathological entity; but an ordinary, or as the French express it, banal inflammation of the skin and mucous membranes, such as can be produced by any form of trauma, or microbic activity, modified by some underlying general constitutional disorder or state, in such a way as to lead to healing by destructive changes and atrophy, rather than to complete restitution of the part.

\begin{tabular}{|c|c|c|c|}
\hline Case. & Circulation Anomalies. & $\begin{array}{c}\text { Condition of the Anricles of } \\
\text { the Ear. }\end{array}$ & $\begin{array}{l}\text { Condition of the Mucous Mem- } \\
\text { branes of the Mlouth. }\end{array}$ \\
\hline $7 \mathrm{C}$ & Ulcerating chilblains & $\begin{array}{l}\text { Erythema pernio of lo- } \\
\text { bules. No scarring or } \\
\text { atrophy. Conchr not } \\
\text { affected }\end{array}$ & Not noted \\
\hline $36 \mathrm{~A}$ & $\begin{array}{l}\text { Severe chilblains. Cold } \\
\text { hands even in summer. } \\
\text { Dry atrophic state of fin- } \\
\text { gers }\end{array}$ & $\begin{array}{l}\text { Erythema pernio of lo- } \\
\text { bules. Pitting from old } \\
\text { ulceration. Conchre not } \\
\text { affected }\end{array}$ & $\begin{array}{l}\text { Atrophic patches on buc- } \\
\text { cal mucous membrane } \\
\text { Lingual and sublingual } \\
\text { papilla very prominent }\end{array}$ \\
\hline $12 \mathrm{~N}$ & $\begin{array}{l}\text { Dead fingers (syncope). } \\
\text { No chilblains }\end{array}$ & Nil & Nil \\
\hline $15 \mathrm{H}$ & $\begin{array}{l}\text { Dead fingers (syncope) } \\
\text { Chilblains on front and } \\
\text { back of fingers near the } \\
\text { joints }\end{array}$ & $\begin{array}{l}\text { Helix and lobules not } \\
\text { affected. Scaly erythema } \\
\text { of concha. }\end{array}$ & Not noted \\
\hline$-G$ & $\begin{array}{l}\text { High tension due to } \\
\text { Bright's disease. Fre- } \\
\text { quent and dangerous } \\
\text { thrombosis of veins }\end{array}$ & $\begin{array}{l}\text { Lobules and helix not } \\
\text { affected. Scaly erythema } \\
\text { in concha. }\end{array}$ & $\begin{array}{l}\text { Multiple cystio degene- } \\
\text { ration (Ranula) floor of } \\
\text { mouth. Increase of stra- } \\
\text { tified epithelium atrophy } \\
\text { over hard palate }\end{array}$ \\
\hline $39 \mathrm{~W}$ & $\begin{array}{l}\text { Dead fingers. No chil- } \\
\text { blains. Marked telangi- } \\
\text { ectasis of vessels of cheeks }\end{array}$ & $\begin{array}{l}\text { Erythema pernio of lo- } \\
\text { bules and helix. Super- } \\
\text { ficial excoriation. Pitted } \\
\text { scars of old ulceration }\end{array}$ & $\begin{array}{l}\text { Glossy tongue. Mucous } \\
\text { membrane of mouth white } \\
\text { and thickened. Sublin- } \\
\text { gual papillø prominent }\end{array}$ \\
\hline $3 \mathrm{~W}$ & $\begin{array}{l}\text { Ulcerating chilblains } \\
\text { on hands and ears for } \\
\text { many years }\end{array}$ & $\begin{array}{l}\text { Marked pitting and } \\
\text { atrophy of lobules and } \\
\text { helix }\end{array}$ & $\begin{array}{l}\text { Atrophic patches on } \\
\text { buccal mucous mem- } \\
\text { brane. Sublingual pa- } \\
\text { pillæ prominent }\end{array}$ \\
\hline $14 T$ & $\begin{array}{l}\text { Cyanosis of cheeks and } \\
\text { hands (asphyxia). Hands } \\
\text { swollen. Always chil- } \\
\text { blains }\end{array}$ & $\begin{array}{l}\text { Pitting and atrophy of } \\
\text { lobules and belix. Con- } \\
\text { cha not affected }\end{array}$ & $\begin{array}{l}\text { Sunken, bright red, } \\
\text { atrophic patches covering } \\
\text { hard palate. Increase of } \\
\text { stratified epithelium }\end{array}$ \\
\hline $40 \mathrm{M}$ & $\begin{array}{l}\text { Hands swollen. Tip of } \\
\text { nose swollen }\end{array}$ & $\begin{array}{l}\text { Erythema pernio of lo- } \\
\text { bules. Orange-peel con- } \\
\text { dition of concha }\end{array}$ & $\begin{array}{l}\text { Small } \\
\text { patches. Verythematous smooth } \\
\text { tongue. Mueous mem- } \\
\text { brane swollen and lumpy }\end{array}$ \\
\hline
\end{tabular}




\begin{tabular}{|c|c|c|c|}
\hline Case. & Circulation Anomalies. & $\begin{array}{l}\text { Condition of the Auricles of } \\
\text { the Ear. }\end{array}$ & $\begin{array}{l}\text { Condition of tho Mucous Mem- } \\
\text { branes of the Mouth. }\end{array}$ \\
\hline $29 \mathrm{D}$ & $\begin{array}{l}\text { Severe chilblains for } \\
\text { years on feet, hands and } \\
\text { ears }\end{array}$ & $\begin{array}{l}\text { Lobules and helix ap- } \\
\text { pear normal. Erythema } \\
\text { of concha }\end{array}$ & $\begin{array}{l}\text { Atrophic white patches. } \\
\text { Atrophy over hard palate. } \\
\text { Cyst - like granulations } \\
\text { near lips }\end{array}$ \\
\hline $41 \mathrm{P}$ & None & $\begin{array}{l}\text { Lobules and helix not } \\
\text { affected. Frythema of } \\
\text { concha }\end{array}$ & $\mathrm{Nil}$ \\
\hline $17 \mathrm{R}$ & None & $\begin{array}{l}\text { Lobules and helix not } \\
\text { affected. Orange - peel } \\
\text { condition of concha }\end{array}$ & $\begin{array}{l}\text { Opaque white patches } \\
\text { on buccal mucous mem- } \\
\text { brane }\end{array}$ \\
\hline $18 \mathrm{H}$ & $\begin{array}{l}\text { When a boy had very } \\
\text { severe ulcerating chil- } \\
\text { blains of ears }\end{array}$ & $\begin{array}{l}\text { Much pitting of lobules } \\
\text { and helix. Complete } \\
\text { atrophy of soft parts of } \\
\text { ear. Orange-peel condi- } \\
\text { tion of concha }\end{array}$ & Nil \\
\hline $38 \mathrm{~S}$ & Cold extremities & $\begin{array}{l}\text { Nil on helix and lo- } \\
\text { bules. Erythema and } \\
\text { large comedones in con- } \\
\text { cha }\end{array}$ & Not noted \\
\hline $4 \mathrm{G}$ & $\begin{array}{l}\text { None discovered. Yet } \\
\text { patient very debilitated } \\
\text { and unhealthy }\end{array}$ & $\begin{array}{l}\text { Nil on helix and lo- } \\
\text { bules. Orange-peel con- } \\
\text { dition of concha }\end{array}$ & Nil \\
\hline
\end{tabular}

Taking the columns in order, one finds under

(a.) Circulation anomalies.

Nothing

Ulcerating chilblains or evidence of their previous

existence . . . . . . . . . . . in 5 cases.

Severe non-ulcerating chilblains . . . . . in 3 cases.

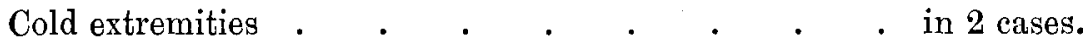

Dead fingers (local syneope) . . . . . . in 3 cases.

Local asphyxia in one and probably . . . . . in 2 cases. Marked telangiectasis of face . . . . . in 1 case.

It will be noted that more than half (8) of the cases suffer, or have suffered, from more or less persistent chilblains, and five, i.e., one-third of the whole of them, from the ulcerating type.

No account has been taken of occasional chilblains that disappear readily. In these cases the chilblains were persistent, slow to heal, and in several instances so closely associated with the disease, that it was impossible to say where the ordinary chilblain ended and the disease began. 
I shall return to this matter later. At present it is only necessary to emphasize an association, so frequently pointed out by others.

Two cases suffered from coldness of the extremities to an unusual degree, and three from local syncope of the hands. Only two of these suffered from chilblains, one in the first group and one in the second.

One case suffered from marked cyanotic flushing of face and hands, and in this instance chilblains were very severe and persistent.

Considering the total number of cases in the series, it is evident that these instances of periodic or permanent interference with the circulation are relatively very numerous, representing as they do more than one-third of the total.

One case (aged 34) presented an unusual degree of Telangiectasis of the face, which had been present for many years before the disease showed itself ; and it is interesting to record that the mother of Case $40 \mathrm{M}$., a child with very extensive manifestations of the disease, showed the same markedly dilated condition of the vessels of the face, though she was otherwise unaffected. I have a very strong impression that there is a much closer connection between Telangiectasis of the face and Lupus erythematosus than appears in this table. I have not investigated the point at all; but my recollection of cases suggests that the two are by no means infrequently associated. Crocker actually describes a telangiectic type.

To my mind the table supports, in the strongest possible manner, the contention that the great majority of cases suffer from some anomaly of circulation that leads to impairment of the nutrition of the peripheral vessels, so that they are unable to bear the strain laid on them by the ordinary body requirements, the ordinary external influences, such as atmospheric changes, trauma, microbic activity, etc., and respond to the same by degeneration and obliteration, with consequent atrophy and disappearance of the parts depending on them for nourishment.

It is unnecessary to labour this point now, as I shall return to it on a future occasion.

With reference to the next column on the table I ought to mention that I included it in order to inform myself as to the nature of the lesion met with on the auricles of the ear. The typical orange-peel 
condition is always mentioned; but as a matter of fact it is not so commonly encountered as one would be inclined to expect. It is in examining the state of the lobules and helix that one becomes impressed with the very close connection between chilblains and the disease under consideration. Hence I make no apology for inserting the observations here.

(b.) Condition of the Auricles of the Ear.

Erythema pernio of helix and lobule without ulceration . . . . . . . . . . in 2 cases. Erythema pernio of helix and lobule with ulceration - in 2 cases. Complete atrophy of soft part of helix and lobule . . in 3 cases. Scaly erythema of concha, resembling that encountered

in the meatus . . . . . . . . in 5 cases. Typical orange-peel state of concha . . . . in 3 cases.

Thus the concha of the ear was affected in eight, or more than half, the cases, whilst the orange-peel condition was found only in three.

In seven cases the helix and lobules were affected, and in three of these the soft parts had atrophied more or less completely. In the remaining cases the lesions bore the closest resemblance to ordinary chilblains, and could only be distinguished by their long duration and resistance to treatment.

In one instance the whole lobule was red and hot; but in the other cases there were small, deep-lying erythematous nodules, often not much larger than a hemp-seed, and lying scattered over the surface of the lobule and helix, more particularly affecting the free border.

Sometimes these were scaly, sometimes superficially ulcerated, and the evidence of past ulceration was given by a number of small pits and depressed scars.

It is hard, if not impossible, to separate these lesions from ordinary chilblains. They come and go in the same fashion at first, and then become by degrees more or less permanent. They lead in time to the complete atrophy of soft parts, noted in three cases.

(c.) Condition of the Mucous Membrane of the Mouth.

Small erythematous patches on buccal mucous membrane just in front of the ramus of the jaw . . . . . in 1 case. Mother-of-pearl atrophic patches in same situation . in 4 cases. 
Atrophy of mucous membrane of the tongue . . . in 2 cases. Atrophy over the hard palate . . . . . in 3 cases, Mucous membrane, as a whole, swollen with increase of stratified epithelium . . . . . . . . in 4 cases. Increased prominence of orifices of ducts . . . . in 3 cases. Multiple cystic degeneration (ranula) of the floor of the mouth . . . . . . . . . in 1 case. Small yellow retention cysts on buccal mucous membrane near the margin of the lips . . . . in 3 cases. Nothing observed . . . . . . . . . . in 4 cases. Not noted . $\quad . \quad . \quad . \quad . \quad . \quad . \quad . \quad . \quad$ in 3 cases.

Seven of the fifteen cases were either normal or the condition was not noted. Hence the figures given apply really to eight, and their number gains increased importance.

The conditions, found, roughly fall into three classes : (1) Atrophic patches of greater or less extent; (2) swelling of whole mucous membrane with increase of stratified epithelium; (3) various retention phenomena.

(1) The Atrophic Patches.-These most commonly occur on the buccal mucous membrane between the molar teeth and a little in front of the ramus of the jaw. The patches resemble mother-ofpearl in that they are covered with thickened surface epithelium and they appear sunk into the surrounding mucous membrane. In one case there were bright erythematous patches of the same size, and in the same situation; and this is suggestive, since the child (40 M.) had just shown a recent involvement of the mucous membrane of the nose in the form of hypertrophic rhinitis.

In two cases the mucous membrane of the eides of the tongue, encroaching considerably on to the dorsum, was atrophic. In one of these cases it was so marked as to deserve the designation glossy tongue.

In three cases I noted a peculiar atrophy of the mucous membrane covering the hard palate. The surface appeared sunken and the vessels unusually prominent and large.

In one instance this area was bright red, infiltrated and covered by narrow bands and circles of shining, thickened stratified epithelium. In fact, it exactly resembled the patches met with on the 
skin. In the next section I shall refer to a case that throws a light on this atrophy over the hard palate.

(2) Swelling of the whole Mucous Membrane with Increase of Stratified Epithelium.-This was seen in four cases. The mucous membrane was clearly swollen and dull white in colour, due apparently to a thickening of the stratified epithelium. The surface was marked by exaggerated natural folds, such as one observes in a lichenised patch or on an ichthyotic skin.

In one case (-G.) the membrane covering the hard palate is enormously thickened, sodden and raised in folds. It looks as if it would exfoliate readily, and yet $I$ have observed it for many months.

In another case the membrane is white and lumpy, reminding one of the condition of the nose in the same case.

In association with this condition one finds the papillæ marking the orifices of various ducts very much enlarged. One case had a group of large red swollen papillæ on the under surface of the tongue just where the frenum is attached. They form a marked picture and are present, I believe, more frequently than the table indicates.

The explanation of their origin appears to be in the thickening of the stratified epithelium, and consequently obstruction to the passage of the contents of the ducts.

(3) Retention Phenomena.--In three cases I found a multitude of small yellow retention cysts or blocked glands on the buccal mucous membrane just inside the lips. I examined very few cases for this appearance. It is by no means peculiar to Lupus erythematosus, but does indicate an increase of the surface and particularly of the stratified epithelium.

I have mentioned a multiple ranula of the floor of the mouth, not because I think it has anything to do with Lupus erythematosus, but because I believe it owes its origin to that same thickening of the epithelium.

It is a curious coincidence that the patient in whom it developed had also the yellow cyst-like swellings on the buccal mucous membrane, a Meibomian cyst and considerable swelling of the orifices of the ducts in the mouth.

In four cases the mucous membranes of the mouth appeared healthy, but this does not imply that they necessarily were so. I 
have only included such gross changes as were obvious to the eye and about which there could be no dispute. The impression I gather from examining these cases is that there might be a general atrophy corresponding to that in the nose, and yet extremely hard to detect. In one case in particular I had many reasons for believing that there was such an atrophy, but as the matter was doubtful I put it down as healthy.

It only remains for me to give a list of the cases showing the parts affected.

7 C. Lobules of ears. Bridge of nose. Scaly erythema. Atrophy slight.

36 A. Lobule of one ear. Scaly erytheme of four years' duration.

12 N. Bridge and sides of nose. Sealy erythema. Small round atrophic patch in naso-labial groove.

$15 \mathrm{H}$. Scalp only and hairy part in front of ear. Concha.

- G. Scalp and part in front of ear. Concha. (Male.)

$39 \mathrm{~W}$. Butterfly area-lobules of ears and helix.

$3 \mathrm{~W}$. Right side of cheeks. Lobules of ears and helix.

14 T. Right cheek. Left naso-labial groove. Right upper eyelid. Free edge of ears and lobules.

$40 \mathrm{M}$. Scalp in large patches. Great part of face. Lobule of ears. Concha. Hands.

29 D. Right side of cheek, commencing on the left concha.

$41 \mathrm{P}$. Great part of face in patches, upper eyelids. Concha.

17 R. Practically the whole scalp. Concha. Many large atrophic patches on the face.

18 H. Whole face and ears. Commencing in scalp. Front and back of chest, large atrophic scaly areas. Deltoid region on either side. (Male.)

$38 \mathrm{~S}$. Scalp in patches. Concha. Commencing on side of nose.

$4 \mathrm{G}$. Scalp in patches. Face ditto. Concha. One small patch on front of chest. Frequent and grave relapses after improvement. 